\title{
Penerapan Metode Tutor Sebaya \\ Untuk Meningkatkan Keterampilan \\ Berfikir Kritis Siswa Dalam Pembelajaran Matematika (Studi Kasus Di Kelas XI MIA-3 MAN Sipirok Tapanuli Selatan)
}

\author{
Almira Amir* \\ Email: almira@iain-padangsidimpuan.ac.id \\ Fakultas Tarbiyah dan Ilmu Keguruan IAIN Padangsidimpuan
}

\begin{abstract}
This research is based on the background of students' low critical thinking skills in classroom learning. This is caused by the conventional learning process, and using learning methods that are less varied. to overcome the low critical thinking skills students can use peer tutoring learning methods that require students to be more active, critical during the learning process.

This study aims to determine the improvement of students' critical thinking skills in trigonometry material using peer tutoring learning methods in class XI MIA-3 MAN Sipirok, through peer tutoring learning methods are expected to be more active and meaningful learning for students so that they are ultimately able to provide and improve thinking skills critical students in trigonometry material.

The type of research used is PTK (classroom action research) using two cycles, and each cycle 2 meetings. One cycle consisted of planning (planning), action (action), observasi (observation) and refleksi (reflection), this sub-research was class XI MIA-3 MAN Sipirok 2017/2018 academic years consisting of 37 students.

Based on the results of the research conducted, it can be concluded that by using the peer tutoring method that is able to obtain an increase in students' critical thinking skills in the subject matter of trigonometry in class XI MIA-3 MAN Sipirok in each cycle the improvement of critical thinking skills occurs in overall critical thinking, so the results of the increase in critical thinking of students from the first cycle of meeting I of meeting I $51,35 \%$ be $62,16 \%$ cycle of meeting II cycle of meeting I, cycle II of meeting I $75,68 \%$ be $86,48 \%$ cycle II of meeting.

Thus the critical thinking skills of students in class XI MIA-3 MAN Sipirok achieved through Peer Tutoring learning methods have reached the highest percentage in this study which is $86.48 \%$.
\end{abstract}

Keywords: critical thinking, peer tutoring, trigonometry, mathematics learning, mathematics

\footnotetext{
* Correspondence:

Email: almira@iain-padangsidimpuan.ac.id
} 


\begin{abstract}
Abstrak
Penelitian ini dilatar belakangi oleh rendahnya keterampilan berpikir kritis siswa dalam pembelajaran di dalam kelas. Hal ini disebabkan oleh proses pembelajaran yang belum menggunakan metode pembelajaran yang bervariasi. Untuk mengatasi rendahnya keterampilan berpikir kritis siswa maka digunakan metode Tutor Sebaya yang mengharuskan siswa lebih aktif, kritis selama proses pembelajaran.

Penelitian ini bertujuan untuk mengetahui peningkatan keterampilan berpikir kritis siswa pada materi Trigonometri dengan menggunakan metode Tutor Sebaya di kelas XI MIA-3 MAN Sipirok. Melalui penerapan metode Tutor Sebaya diharapkan pembelajaran lebih aktif dan bermakna bagi siswa sehingga pada akhirnya akan mampu memberikan dan meningkatkan keterampilan berpikir kritis siswa pada materi Trigonometri.

Jenis penelitian yang digunakan ialah PTK (Penelitian Tindakan Kelas) dengan menggunakan 2 siklus, dan setiap siklus 2 kali pertemuan. Satu siklus terdiri dari perencanaan (planning), tindakan (action), pengamatan (observasi), dan Refleksi (Reflection). Subjek penelitian ini adalah kelas XI MIA-3 MAN Sipirok tahun ajaran 2017/2018 yang terdiri dari 37 siswa.

Berdasarkan hasil penelitian yang dilakukan, maka dapat disimpulkan bahwa dengan menggunakan metode Tutor Sebaya yang dilakukan mampu memperoleh peningkatan keterampilan berpikir kritis siswa pada materi pokok bahasan Trigonometri di kelas XI MIA-3 MAN Sipirok pada setiap siklus peningkatan keterampilan berpikir kritis terjadi pada keseluruhann berpikir kritis, sehingga diperoleh hasil peningkatan berpikir kritis siswa dari siklus I pertemuan I dari $51,35 \%$ menjadi $62,16 \%$ siklus I pertemuan II dan siklus II pertemuan I dari $75,68 \%$ menjadi $86,48 \%$ siklus II pertemuan II.

Dengan demikian keterampilan berpikir kritis siswa di kelas XI MIA-3 MAN Sipirok yang dicapai melalui metode pembelajaran Tutor Sebaya sudah mencapai persentase paling tinggi dalam penelitian ini yaitu $86,48 \%$.
\end{abstract}

Kata Kunci: berpikir kritis, tutor sebaya, trigonometri, pembelajaran matematika, matematika

\title{
A. PENDAHULUAN
}

Matematika merupakan salah satu mata pelajaran yang diterapkan mulai dari jenjang Sekolah Dasar sampai jenjang Sekolah Menengah Atas dan selalu diaplikasikan dalam kehidupan sehari-hari. Salah satu contoh penerapan Matematika dalam kehidupan sehari-hari diantaranya dalam konsep jual beli. Matematika merupakan ilmu universal yang mendasari perkembangan teknologi modern sehingga memiliki peranan yang sangat penting dalam setiap disiplin ilmu dan dapat memajukan daya pikir manusia. Oleh sebab itu, dibutuhkan penguasaan konsep Matematika yang kuat dari peserta didik sejak dini agar dapat menguasai ilmu pengetahuan dan menciptakan teknologi di masa depan. 
Untuk dapat menguasai dan menciptakan IPTEK maka peserta didik harus belajar dimana saja, kapan saja dan kepada siapa saja. Keberhasilan bisa diraih bergantung pada proses belajar yang dialami peserta didik di sekolah ataupun di lingkungan rumah dan masyarakat ${ }^{1}$. Belajar dapat diartikan sebagai suatu proses dimana seseorang dapat berubah perilakunya sebagai akibat dari pengalaman yang diperolehnya. Menurut Djamarah, belajar adalah serangkaian kegiatan jiwa raga untuk memperoleh suatu perubahan tingkah laku sebagai hasil dari pengalaman individu dalam interaksi dengan lingkungannya yang menyangkut kognitif, afektif, dan psikomotor ${ }^{2}$. Pengalaman belajar juga dapat diperoleh di sekolah dalam proses pembelajaran di kelas.

Berdasarkan pengertian di atas dapat disimpulkan bahwa belajar ialah suatu proses atau kegiatan yang dilakukan sehingga membuat suatu perubahan perilaku yang berbentuk kognitif, afektif, maupun psikomotorik dengan berbagai latihan dan pengalaman. Melalui mata pelajaran Matematika, dapat membekali siswa memiliki kemampuan berpikir logis, analitis, sistematis, kritis, dan kreatif serta mampu bekerja sama untuk memperoleh, mengelola, dan memanfaatkan informasi agar tetap dapat bertahan hidup pada keadaan yang selalu berubah dan semakin penuh persaingan di era globalisasi ini. Guna mencapai hal tersebut maka diperlukan seorang guru sebagai pendidik yang memiliki peran menjadi sumber belajar, fasilitator, pembimbing dan motivator.

Seorang guru harus memiliki keterampilan mengajar dalam membelajarkan peserta didik. Seorang guru harus kaya metode dan strategi mengajar yang bertujuan agar siswa dapat menjadi pelaku yang aktif dalam mengembangkan potensinya. Setiap siswa memiliki karakterisktik dan potensi yang berbeda, sehingga seorang guru dituntut untuk mampu berinovasi dan berkreasi agar menjadikan pembelajaran di kelas menjadi lebih bermakna. Kebermaknaan belajar Matematika akan dirasakan apabila tumbuh minat belajar, siswa tidak merasakan kesulitan dalam belajar sehingga hasil belajar siswa menjadi lebih baik. Hasil belajar Matematika yang rendah menunjukkan bahwa siswa kesulitan dalam memahami konsep-konsep dalam materi yang terdapat dalam Matematika. Beberapa faktor yang mempengaruhi hasil belajar siswa di antaranya adalah, kurang berani bertanya, kurangnya waktu belajar di rumah, lebih senang bercerita atau bercanda dengan teman sebangkunya.

Hasil belajar siswa umumnya hanya dikenal berupa kemampuan menjelaskan suatu konsep, melakukan operasi atau prosedur-prosedur, menyelesaikan suatu soal yang rutin atau menerapkan suatu konsep. Karena kemampuan berpikir kritis merupakan kemampuan yang sangat diperlukan karena berpikir kritis dan matematika merupakan satu kesatuan yang tidak dapat dipisahkan. Materi matematika dipahami melalui berpikir kritis dan dilatih melalui serangkaian proses dalam pembelajaran matematika. Kemampuan berpikir kritis diartikan sebagai kegiatan penalaran yang beroriantasi pada suatu proses intelektual yang melibatkan pembentukan konsep, aplikasi, analisis, ataupun penilaian dari suatu informasi untuk memecahkan suatu masalah. Keterampilan berpikir kritis dan kemampuan berpikir kritis dalam penilaian hasil belajar harus saling bersinergi secara seimbang dalam pelaksanaan pembelajaran matematika

\footnotetext{
${ }^{1}$ Muhibbin Syah, Psikologi Belajar (Jakarta: Raja Grafindo Persada, 2006), hlm. 63.

${ }^{2}$ Syaiful Bahri Djamarah, Psikologi Belajar (Jakarta: Aneka Cipta, 2002), hlm. 13.
} 
untuk melatih siswa dalam menganalisis pemikirannya sendiri dalam memutuskan suatu pilihan dan menarik kesimpulan, serta untuk meningkatkan hasil belajar.

Dalam pemilihan metode belajar yang baik, seorang guru harus dapat menentukan model pembelajaran yang tepat agar hasil belajar Matematika menjadi lebih baik. Salah satu model pembelajaran yang digunakan adalah memanfaatkan tutor sebaya (peer teaching). Pemilihan metode pembelajaran tutor sebaya merupakan salah satu alternatif yang dapat diterapkan kepada siswa dalam proses pembelajaran yang dilakukan dengan kelompok kecil. Tujuan dari proses pembelajaran melalui kelompok kecil adalah : 1) dapat meningkatkan partisipasi optimal siswa dalam belajar, 2) dapat memberi pelajaran kepemimpinan dan pengalaman dalam membuat keputusan kelompok, 3) dapat memberi kesempatan untuk berinteraksi dengan siswa yang berasal dari latar belakang kebiasaan dan kemampuan yang berbeda ${ }^{3}$. Dengan metode pembelajaran secara berkelompok yang di pimpin oleh seorang tutor diharapkan siswa memiliki kemampuan yang lebih baik secara kognitif dan keterampilan.

Beberapa hasil penelitian yang telah menerapkan metode tutor sebaya diantaranya Rena Ayu Triyunita, menyatakan bahwa dengan penggunaan metode tutor sebaya dapat meningkatkan suasan keakraban dan kerjasama antar teman sebaya melalui proses diskusi dan kemampuan berpikir kritis siswa tergolong baik. $^{4}$ Peneliti lainnya, Rinda Aryanti Wahyudin menyatakan bahwa rata-rata peningkatan kemampuan pemahaman konsep matematika siswa lebih baik dengan menggunakan metode pembelajaran tutor sebaya ${ }^{5}$. Hasil penelitian Siti Hardiyanti, dkk., menunjukkan bahwa melalui metode tutor sebaya, ada peningkatan kemampuan siswa dalam menyelesaikan pertidaksamaan linear satu variabel ${ }^{6}$.

\section{Berpikir Kritis dalam Pembelajaran Matematika}

Matematika merupakan ilmu pengetahuan yang bersifat deduktif yang memerlukan pembuktian. atematika mempelajari tentang pola, struktur, keteraturan yang terorganisasi, yang dimulai dari unsur-unsur yang tidak terdefinisikan kemudian ke unsur-unsur yang terdefinisikan, terus ke aksioma atau postulat sampai ke dalil-dalil atau teorema ${ }^{7}$. Dalam matematika, kebenaran dapat dibuktikan dengan memeriksa konsistensi suatu konsep dengan konsep sebelumnya yang telah dianggap benar. Kebenaran matematika

3 Kosasih, E., Strategi Belajar dan Pembelajaran (Implementasi Kurikulum 2013). (Bandung: Yrama Widya, 2014), hlm. 101.

${ }^{4}$ Rena Ayu Triyunita, Pengaruh Metode Tutor Sebaya Terhada Kemampuan Berpikir Kritis Siswa Kelas X SMA Negeri 3 Kediri Dalam Menyelesaikan Permasalahan Terkait Komposisi Fungsi (Artikel Skripsi: Universitas Nusantara PGRI Kediri, 2018).

5 Rinda Aryati Wahyudin, Metode Pembelajaran Tutor Sebaya Untuk Meningkatkan Kemampuan Pemahaman Konsep Matematika Siswa Kelas VII SMP Negeri 2 Teluk Jambe Timur. Prosiding Seminar Nasional Matematika dan Pendidikan Matematika (SESIOMADIKA), 2017, hlm. 534-539.

6 Siti Hardiyana, dkk., Penerapan Pendekatan Tutor Sebaya Untuk Meningkatkan Kemampuan Siswa Kelas VII SMP Negeri 1 Kasimbar Dalam Menyelesaikan Pertidaksaman Linear Satu Variabel, AKSIOMA Jurna Pendidikan Matematika Vol. 04 No. 02 September 2015.

7 Lambertus, Pentingnya Melatih Keterampilan Berpikir Kritis dalam Pembelajaran Matematika SD. Forum Kependidikan, 2009, 28 (2), 136-142. 
tidak tergantung pada pembuktian secara empiris melainkan tergantung pada pembuktian secara deduktif ${ }^{8}$.

Dalam pembuktian secara deduktif, kesimpulan yang ditarik merupakan akibat logis dari alasan-alasan yang bersifat umum menjadi bersifat husus. Penerapan pembuktian secara deduktif ini akan menghasilkan teorema-teorema untuk menyelesaikan masalah-masalah baik dalam rumpun matematika maupun pada rumpun ilmu-ilmu yang lain. Karakteristik matematika yang khas dan kompleksitas mengharuskan peserta didik mampu dan terampil berpikir kritis dalam mempelajari matematika. Glazer dalam Sumarmo menyatakan bahwa berpikir kritis dalam matematika merupakan kemampuan dan disposisi yang dikombinasikan dengan pengetahuan, kemampuan penalaran matematik, dan strategi kognitif sebelumnya, untuk menggeneralisasikan, membuktikan, mengevaluasi situasi matematik secara reflektif ${ }^{9}$.

Kemampuan dan keterampilan berpikir kritis dalam pembelajaran matematika sangat diperlukan agar siswa dapat memahami dan memecahkan suatu permasalahan matematika yang memerlukan penalaran, analisis, evaluasi dan intrepetasi pikiran. Apabila siswa memiliki kemampuan dan keterampilan berpikir kritis yang baik dalam pembelajaran matematika maka akan dapat memperkecil tingkat kesalahan siswa dalam menyelesaikan soal.

Peningkatkan kemampuan dan keterampilan berpikir kritis dalam pembelajaran matematika sangat diperlukan karena berpikir kritis dan matematika merupakan satu kesatuan yang tidak dapat dipisahkan. Kemampuan berpikir kritis diartikan sebagai kegiatan penalaran yang beroriantasi pada suatu proses intelektual yang melibatkan pembentukan konsep, aplikasi, analisis, ataupun penilaian dari suatu informasi untuk memecahkan suatu masalah. Keterampilan berpikir kritis dipahami sebagai kemampuan yang mengacu pada kemampuan khusus yang diperoleh melalui pengalaman atau latihan untuk melakukan tugas tertentu (Yuni Anjarwati, dkk. ${ }^{10}$; Dany Aminudin dan Hadi Kusmanto ${ }^{11}$ ). Keterampilan berpikir kritis sebagai aspek psikomotorik, dan kemampuan berpikir kritis sebagai aspek kognitif dalam penilaian hasil belajar. Keduanya harus saling bersinergi secara seimbang dalam pelaksanaan pembelajaran matematika untuk melatih siswa dalam menganalisis pemikirannya sendiri dalam memutuskan suatu pilihan dan menarik kesimpulan, serta untuk meningkatkan hasil belajar.

Keterampilan berpikir kritis dalam pembelajaran matematika dapat dikembangkan melalui proses pembelajaran yang berpedoman pada indikator keterampilan berpikir kritis antara lain (1) mengidentifikasi elemen-elemen 1998)

${ }^{8}$ Suriasumantri, J.S. Filsafat Ilmu Sebuah Pengantar Populer (Jakarta: Sinar Harapan,

9 Sumarmo, dkk, Kemampuan dan Disposisi Berpikir Logis, Kritis, dan Kreatif Matematik. Jurnal Pengajaran MIPA, 201617 (1). 17-33.

10 Yuni Anjarwati, Siti Maghfirotun Amin, Agung Lukito, Peningkatan Keterampilan Bepikir Kirits Pada Pembelajaran Geometri Dengan Pendekatan Matematika Realistik Di Kelas IV SDN 1 Pule Kecamatan Pule Kabupaten Trenggalek, Jurnal Kajian Pendidikan dan Hasil Penelitian Vol 2, No 1, Januari 2016.

11 Dany Aminudin dan Hadi Kusmanto, Upaya Meningkatkan Keterampilan Bepikir Kritis dan Keaktifan Siswa Pada Pembelajaran Matematika Melalui Pendekatan Kontruktivisme (Penelitian Tindakan Kelas Pada Siswa Kleas VII SMPN 2 Ciwaru Kab. Kuningan, Mathematics Education Learning and Teaching Published by Tadris Matematika, IAIN Syekh Nurjati Cirebon 
dalam kasus yang dipikirkan (alasan dan kesimpulan); (2) mengidentifikasi dan mengevaluasi asumsi; (3) mengklarifikasi dan menginterpretasi pernyataanpernyataan dan gagasan-gagasan; (4) menilai aksetabilitas (kredibilitas dan klaim); (5) mengevaluasi berbagai argumen; (6) menganalisis, mengevaluasi, dan menghasilkan penjelasan; (7) menganalisis, mengevaluasi, dan membuat kesimpulan; (8) menarik inferensi-inferensi; dan (9) menghasilkan argumen$\operatorname{argumen}^{12}$.

\section{Metode Tutor Sebaya}

Metode pembelajaran yang dapat meningkatkan keterampilan berpikir peserta didik secara aktif dan kreatif salah satunya adalah metode tutor sebaya. Oleh karena itu penerapan metode tutor sebaya diharapkan dapat membantu guru dalam mengajarkan materi kepada peserta didik, karena dalam hal tertentu kadang peserta didik lebih paham dengan bahasa teman sebaya daripada bahasa guru, dan peserta didik tidak merasa malu dan takut untuk menayakan materi yang belum mereka pahami.

Guru yang menggunakan metode pembelajaran tutor sebaya mengacu kepada belajar kelompok, menyajikan informasi baru kepada siswa setiap minggu. Guru membagi siswa menjadi kelompok-kelompok kecil yang terdiri dari 4-5 orang dan terdiri laki-laki dan perempuan yang berasal dari berbagai suku, memiliki kemampuan cerdas, normal, dan lemah. Dalam proses pembelajaran, siswa yang menjadi tutor hendaknya mempunyai kemampuan yang lebih tinggi dibandingkan teman lainnya, sehingga pada saat memberikan bimbingan ia sudah dapat menguasai bahan yang akan disampaikan.

Tutor sebaya hendaknya memiliki nilai diatas rata-rata teman sebayanya dapat memberikan bimbingan dan penjelasan kepada siswa yang mengalami kesulitan dalam belajar dan memiliki kesabaran serta kemampuan memotivasi sisswa dalam belajar. Dalam memilih tutor perlu diperhatikan hal-hal sebagai berikut:

1. Tutor dapat diterima (disetujui) oleh siswa yang mendapat program perbaikan sehingga siswa tidak mempunyai rasa takut atau enggan untuk bertanya kepadanya.

2. Tutor dapat menerangkan bahan perbaikan yang dibutuhkan oleh siswa yang menerima program perbaikan.

3. Tutor tidak tinggi hati, kejam atau keras hati terhadap sesama kawan.

4. Tutor mempunyai daya kreativitas yang cukup untuk memberikan bimbingan, yaitu dapat menerangkan pelajaran kepada kawannya.

Siswa yang ditunjuk sebagai tutor akan ditugaskan membantu siswa yang akan mendapat program perbaikan, sehingga setiap tutor harus diberikan petunjuk yang sejelas-jelasnya tentang apa yang harus dilakukan. Petunjuk ini memang mutlak diperlukan bagi setiap tutor karena hanya gurulah yang mengetahui kelemahan siswa, sedangkan tutor hanya membantu melaksanakan perbaikan, bukan mendiagnosa.

Metode tutor sebaya merupakan wahana penemuan dan pengembangan konsep. Di dalam proses pembelajaran terjadi interaksi antara siswa yang satu

${ }^{12}$ Fisher, A., Berpikir Kritis: Sebuah Pengantar (Jakarta: Erlangga, 2008), hlm. 8 
dengan siswa yang lain dalam memecahkan masalah yang diberikan oleh guru, sehingga terjadinya sikap meneliti, kreatif, tekun, kerjasama, kritis, tenggang rasa, objektif, bertanggung jawab, jujur, disiplin, dan original. Dengan demikian metode tutor sebaya menekankan kepada kerjasama kelompok dan keterlibatan seluruh siswa dalam menghadapi tugas-tugas klasikal. Pada pembelajaran yang menggunakan kerja kelompok, seperti pada metode tutor sebaya biasanya guru dituntut untuk lebih selektif dalam menentukan kelompok. Dalam pendekatan yang menggunakan kerjasama kelompok biasanya akan meningkatkan keakraban atau saling menyukai satu sama lain, dengan kata lain pendekatan kelompok seperti metode tutor sebaya dapat menumbuhkan rasa saling membutuhkan satu sama lain.

Siswa yang dipilih guru adalah teman sekelas dan memiliki kemampuan lebih cepat memahami materi yang diajarkan, selain itu memiliki kemampuan menjelaskan ulang materi yang diajarkan pada teman-temannya. Karena siswa yang dipilih menjadi tutor ini seumur (sebaya) dengan teman-temannya yang akan diberikan bantuan, maka tutor tersebut sering dikenal dengan sebutan tutor sebaya. ${ }^{13}$

Kelebihan penggunaan teman sebaya sebagai berikut:

1. Siswa termotivasi untuk menjadi tutor sebaya.

2. Dapat mempermudah guru karena dibantu oleh siswa yang berkemampuan

3. Bagi tutor sendiri sebagai kegiatan remedial yang merupakan kesempatann untuk pengayaan dalam belajar dan juga menambah motivasi belajar.

4. Bersifat efesien, artuinya bisa lebih banayak siswa dibantu.

5. Dapat meningkatkan rasa tanggung jawab dan kepercayaan diri siswa.

6. Siswa tidak segan untuk bertanya bila ada yang tidak tahu, sebab dibimbing oleh temannya sendiri.

7. Memotivasi siswa menjadi guru yang profesional.

8. Prosese pembelajaran lebih akrab, karena dilakukan oleh siswa itu sendiri.

Kelemahan penggunaan teman sebaya ini ialah:

1. Tutor sebaya kadang-kadang terlalu bangga dengan tugas yang diberikan oleh guru padanya, sehingga ia meremehkan temannya.

2. Siswa dan guru tidaklah sama dalam memberikan materi, sehingga ada kalanya siswa kurang mengerti.

3. Kemampuan tutor sebaya terbatas sehingga agak sulit dalam mengembangkan materi yang diajarkan. ${ }^{14}$

4. Akan berpotensi pada perlakuan yang diskriminatif dimana pada keadaan tertentu justru sangat merugikan bagi efektifitas pembelajaran. $^{15}$

${ }^{13}$ Rofiqoh Nurhayati, Meningkatkan Kemampuan Siswa dalam Menyelesaikan Soal-soal Cerita Operasi Bilangan Pecahan dengan Menggunakan Pendekatan Tutor Sebaya pada Kelas VIIA SMP Negeri 3 Palangga, hlm. 4-6.

14 Istarani, Kumpulan 40 Metode Pembelajaran, (Medan: Media Persada, 2012), hlm. $150-151$. 


\section{B. METODE}

\section{Tempat dan Waktu Penelitian}

Penelitian dilaksanakan di kelas XI MIA-3 MAN Sipirok beralamat di J1.Sipirok Padangsidimpuan Dusun Danau Situmba Kilang Papan Kec.Sipirok. Penelitian dilaksanakan pada bulan Oktober 2016 sampai dengan Desember 2018.

\section{Jenis Penelitian}

Jenis penelitian yang digunakan Penelitian Tindakan Kelas (PTK) yang merupakan salah satu strategi pemecahan masalah yang memanfaatkan tindakan nyata dan proses pengembangan kemampuan dalam mendeteksi dan memecahkan masalah. Tindakan tersebut diberikan oleh guru atau dengan arahan dari guru yang dilakukan oleh siswa. ${ }^{16}$

\section{Subjek Penelitian}

Subjek penelitian adalah siswa/siswi MAN Sipirok kelas XI MIA-3 yang terdiri dari 37 siswa yang perempuan berjumlah 15 siswa dan laki-laki berjumlah 22 siswa.

\section{Instrumen Data}

Menurut Suharsimi Arikunto instrumen penelitian merupakan alat bantu bagi peneliti dalam mengumpulkan data. ${ }^{17}$ Maka dari itu untuk mengukur suatu tindakan hipotesis diperlukan instrumen sebagai alat ukur. Pada proses penelitian, pengumpulan data banyak digunakan instrumen seperti angket, observasi, wawancara, tes dan lainnya. Adapun jenis instrumen yang digunakan peneliti pada penelitian ini adalah tes, wawancara dan dokumentasi.

\section{Prosedur Penelitian}

Prosedur Penelitian ini adalah penelitian tindakan kelas (Classroom Action Research) yang dilaksanakan dalam siklus yang meliputi perencanaan tindakan (Planning), pelaksanaan tindakan (Acting), pengamatan (Observation), refleksi (Reflecting).

\section{Analasis Data}

Dalam penelitian ini teknik analisis data yang digunakan adalah dengan menggunakan rumus:

$$
\text { Nilai }=\frac{\text { skor yang diperoleh }}{\text { skor maksimal }} \times 100 \%
$$

Persentase keterampilan berpikir kritis siswa secara klasikal dapat dihitung dengan menggunakan rumus:

$$
P=\frac{\sum \text { siswa berketerampilan berpikir kritis }}{\sum \text { siswa }} \times 100 \%
$$

\section{$27-28$.}

${ }^{15}$ Suriyono, Teknik Belajar Mengjar dalam CBSA (Jakarta: PT.Rineka Cipta, 1992), hlm. 2013), hlm. 15-16

${ }^{17}$ Suharsimi Arikunto, Manajemen Penelitian (Jakarta: Rineka Cipta, 2007), hlm. 134. 


\section{HASIL PEMBAHASAN}

Setelah dilakukan tindakan penelitian, data yang diperoleh dari siklus I dan siklus II, karakter pembelajaran siswa maupun keterampilan berpikir kritis siswa pada setiap siklus mengalami peningkatan.

\section{Hasil Tes Keterampilan Berpikir Kritis Siswa Siklus I dan Siklus II}

Tes pada penelitian ini dilakukan disetiap pertemuan yang berfungsi untuk melihat sejauh mana peningkatan keterampilan berpikir kritis siswa.Tes keterampilan berpikir kritis yang diujikan berbentuk essay tes yang terdiri dari 5 soal yang disusun berdasarkan indikator pencapaian keterampilan berpikir kritis siswa tes awal, siklus I pertemuan 1 dan 2, siklus II pertemuan 1 dan 2.

Berdasarkan hasil tes diperoleh bahwa penggunaan metode pembelajaran tutor sebaya dapat meningkatkan keterampilan berikir kritis siswa pada materi Trigonometri. Hal ini dapat dilihat berdasarkan rata-rata hasil tes keterampilan berpikir kritis siswa dan persentase ketuntasan belajar siswa yang semakin meningkat pada setiap pertemuan.

Tabel 4.14

Peningkatan Hasil Tes Keterampilan Berpikir Kritis Siswa

\begin{tabular}{|c|c|c|c|}
\hline Kategori Test & $\begin{array}{c}\text { Rata-Rata } \\
\text { Kelas }\end{array}$ & $\begin{array}{c}\text { Jumlah Siswa } \\
\text { yang Tuntas }\end{array}$ & $\begin{array}{c}\text { Persentase } \\
\text { Ketuntasan } \\
\text { Belajar }\end{array}$ \\
\hline Tes Siklus I Pertemuan-1 & 64,62 & 19 & $51,35 \%$ \\
\hline Tes Siklus I Pertemuan-2 & 72,10 & 23 & $62,16 \%$ \\
\hline Tes Siklus II Pertemuan-1 & 76,56 & 28 & $75,68 \%$ \\
\hline Tes Siklus II Pertemuan-2 & 82,02 & 32 & $86,48 \%$ \\
\hline
\end{tabular}

Berikut diagram ini peningkatan keterampilan berpikir kritis siswa berdasarkan tes yang dilakukan:

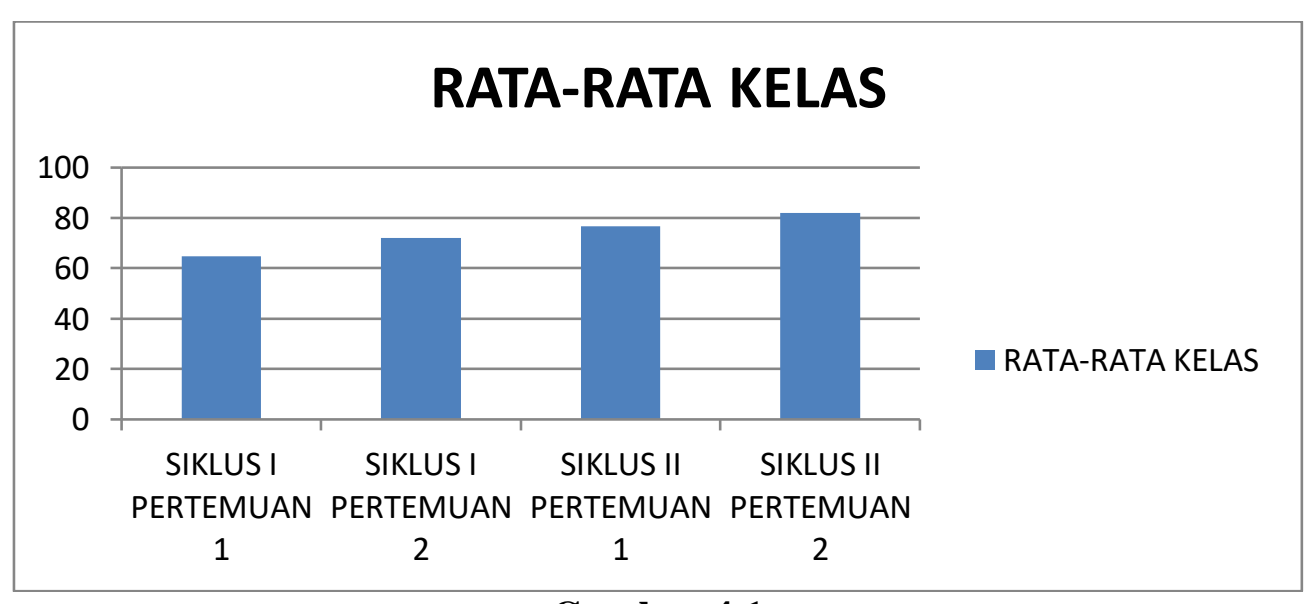

Gambar 4.1

Diagram Batang Peningkatan Nilai Rata-Rata Kelas Keterampilan Berpikir Kritis Siswa 
Sementara untuk persentase ketuntasan belajar siswa digambarkan dalam diagram berikut ini:

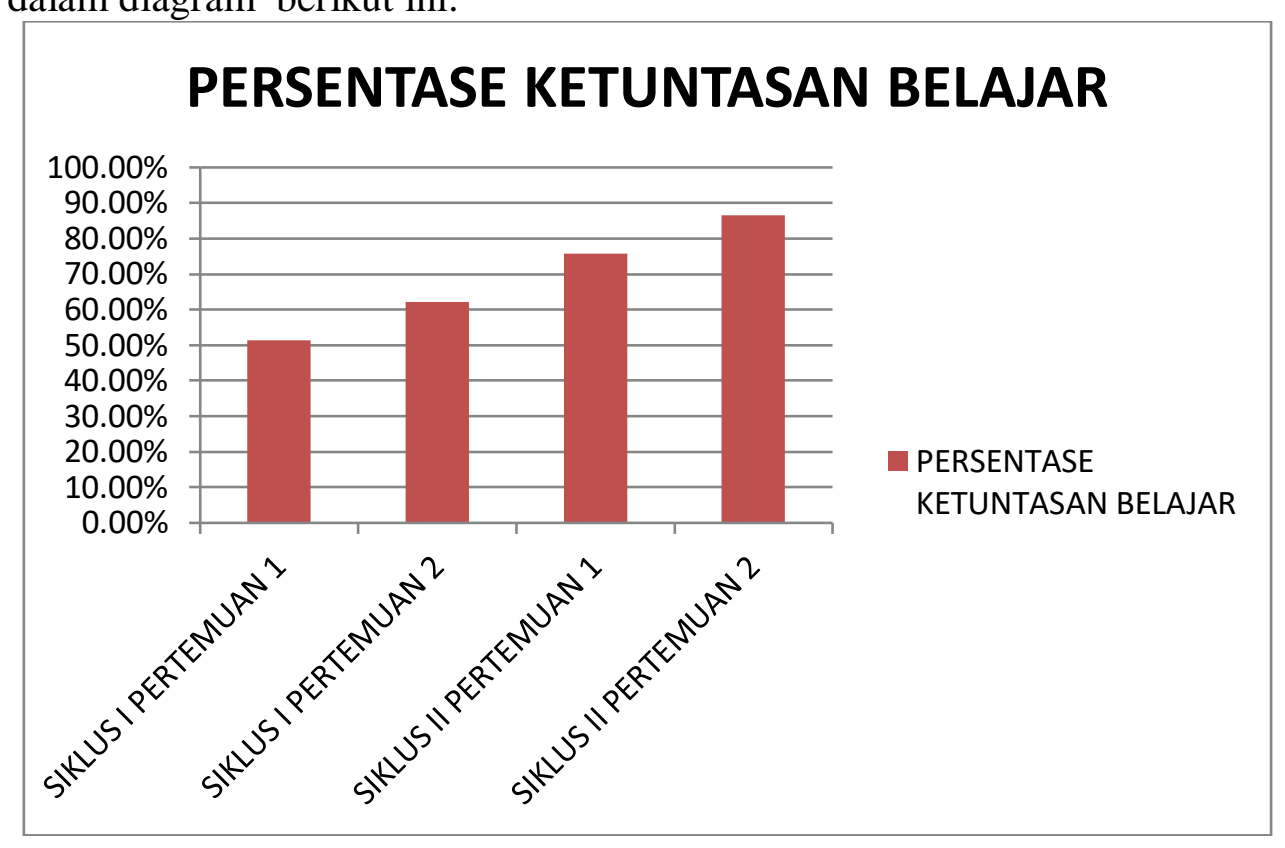

Gambar 4.2

Diagram Batang Peningkatan Persentase Ketuntasan Belajar Berpikir Kritis Siswa

Untuk persentase jumlah siswa yang tuntas digambarkan dalam diagram berikut ini:

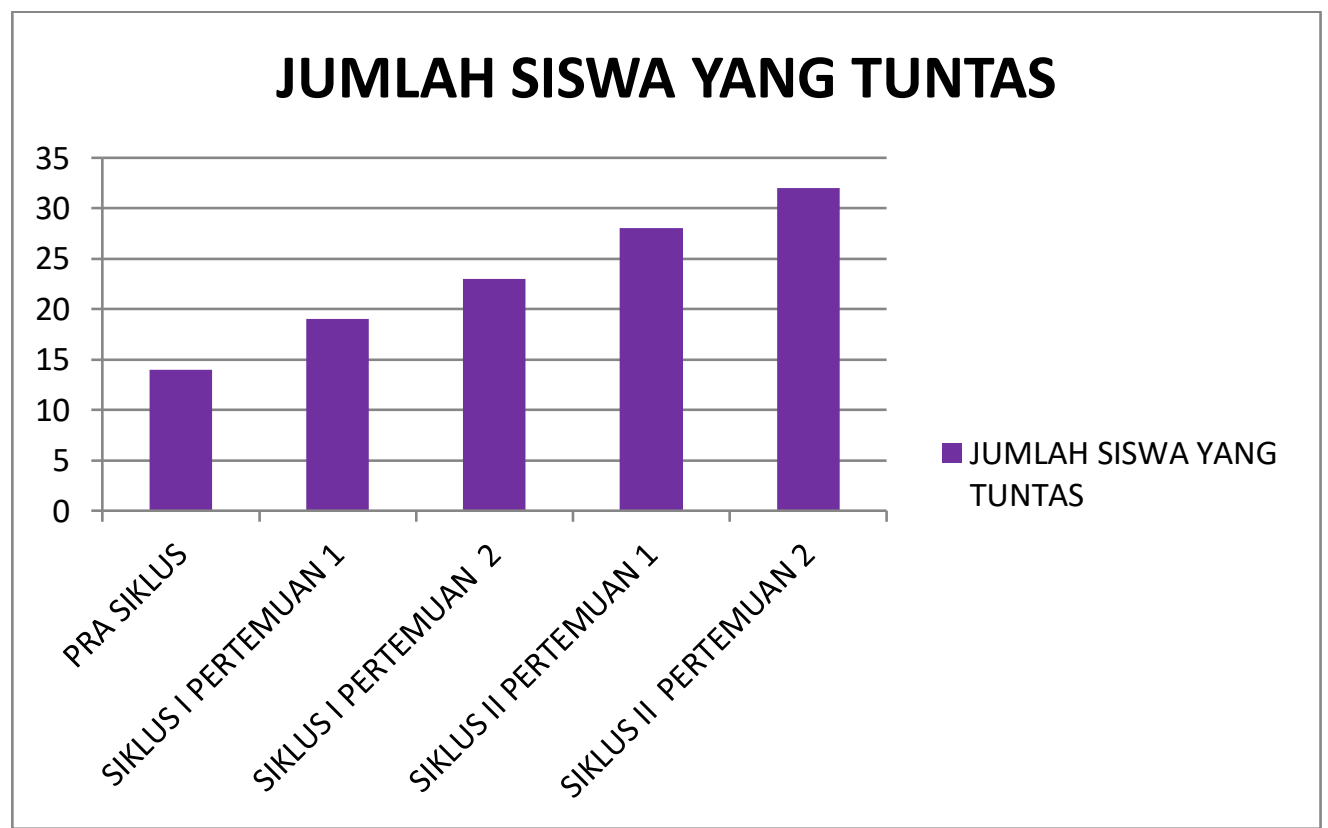

Gambar 4.3

Diagram Jumlah Siswa yang Tuntas 
Tabel 4.15

Peningkatan Keterampilan Berpikir Kritis Matematika pada Siklus I dan Siklus II Berdasarkan Hasil Observasi

\begin{tabular}{|c|c|c|c|c|c|c|}
\hline \multicolumn{2}{|c|}{ Pelaksanaan } & \multicolumn{5}{|c|}{ Indikator } \\
\cline { 3 - 7 } & $\mathbf{1}$ & $\mathbf{2}$ & $\mathbf{3}$ & $\mathbf{4}$ & $\mathbf{5}$ \\
\hline \multicolumn{2}{|c|}{ Observasi Awal } & - & - & - & - & - \\
\hline $\begin{array}{c}\text { Siklus } \\
\text { I }\end{array}$ & Pertemuan 1 & $54,05 \%$ & $54,05 \%$ & $48,65 \%$ & $56,75 \%$ & $43,24 \%$ \\
\cline { 2 - 7 } & Pertemuan 2 & $62,16 \%$ & $56,75 \%$ & $54,05 \%$ & $59,46 \%$ & $54,05 \%$ \\
\hline \multirow{2}{*}{$\begin{array}{c}\text { Siklus } \\
2\end{array}$} & Pertemuan 1 & $75,67 \%$ & $62,16 \%$ & $62,16 \%$ & $67,56 \%$ & $78,37 \%$ \\
\cline { 2 - 7 } & Pertemuan 2 & $96,60 \%$ & $86,48 \%$ & $72,97 \%$ & $70,27 \%$ & $83,78 \%$ \\
\hline
\end{tabular}

Berikut diagram peningkatan keterampilan berpikir kritis matematika berdasarkan tes yang dilakukan pada setiap siklusnya:

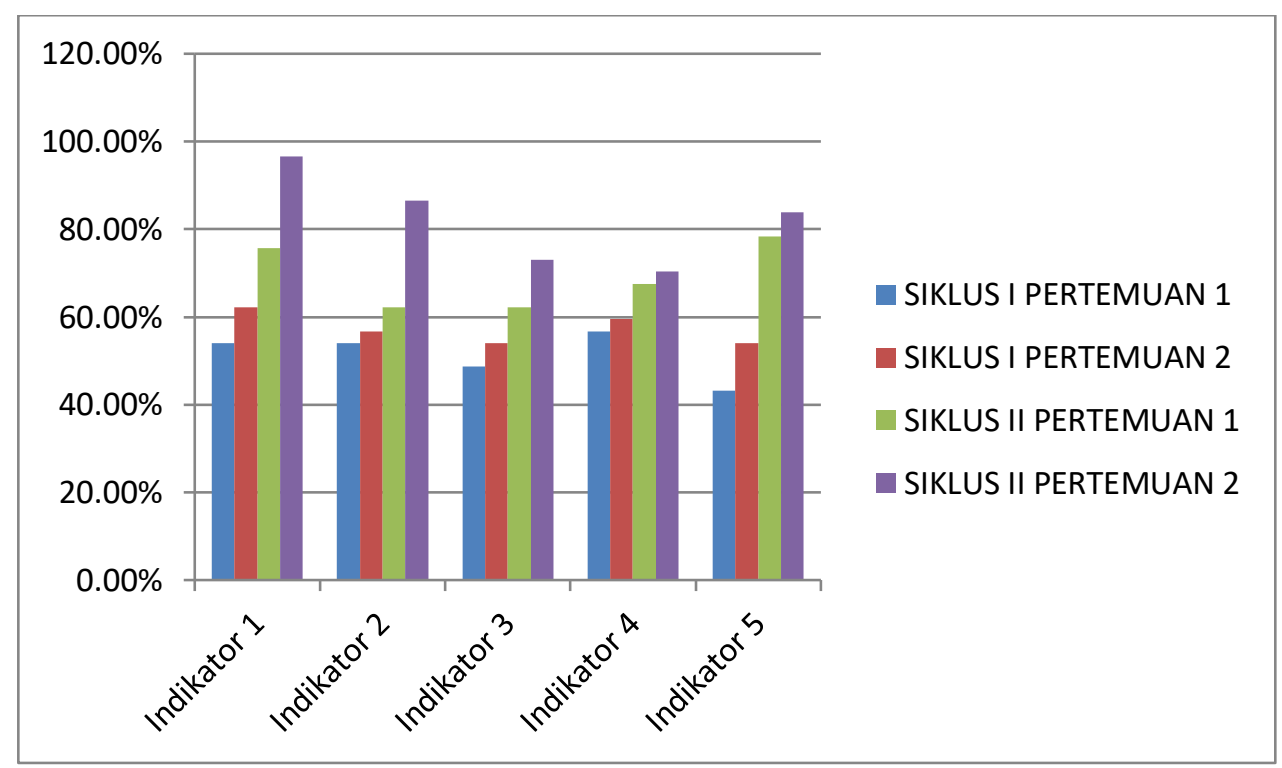

Gambar 4.4

Diagram Peningkatan Keterampilan Berpikir Kritis Matematika Siswa Berdasarkan Hasil Observasi

Dengan demikian berdasarkan diagram peningkatan karakteristik pembelajaran siswa berdasarkan observasi terlihat bahwa jumlah siswa yang berketerampilan berpikir kritis siswa meningkat telah melebihi dari $75 \%$ dari jumlah siswa keseluruhan. Dengan demikian, hipotesis tindakan telah berhasil dicapai yaitu penerapan tutor sebaya dapat meningkatkan keterampilan berpikir kritis siswa pada materi trigonometri di kelas XI MIA-3 MAN Sipirok.

Berdasarkan hasil data yang diperoleh dari siklus I dan II yang diperoleh setiap pertemuan dari hasil tes dan observasi menunjukkan bahwa terjadi peningkatan keterampilan berpikir kritis siswa di kelas XI MIA-3 MAN Sipirok melalui penerapan metode pembelajaran Tutor Sebaya. 
Setelah dilaksanakan penerapan metode pembelajaran tutor sebaya terjadi peningkatan keterampilan berpikir kritis siswa pada setiap pertemuan. Pada tes pertemuan 1 siklus I, dari tes hasil belajar siswa ditemukan terdapat kesulitan pada keterampilan dalam menentukan solusi dalam soal.

Penerapan metode tutor sebaya ini dapat mendorong siswa lebih aktif dan kritis lagi dalam belajar, mampu meningkatkan kerja sama dengan tim, menjadikan siswa memiliki rasa percaya diri menjelaskan atau menyampaikan argumen pada suatu materi, berkomunikasi dengan baik, dan melatih diri siswa menjadi tutor dikala guru sedang ada urusan untuk menciptakan kondisi ruangan belajar yang kondusif dan sistematis. Secara keseluruhan hasil penelitian ini menunjukkan bahwa dengan penerapan metode tutor sebaya dapat meningkatkan keterampilan berpikir kritis siswa pada materi trigonometri di kelas XI MIA-3 MAN Sipirok.

\section{KESIMPULAN}

Berdasarkan hasil penelitian yang telah dilaksanakan dan uraian yang telah dijelaskan sebelumnya, maka dapat disimpulkan bahwa dengan meenerapkan metode Tutor Sebaya ada peningkatan keterampilan berpikir kritis siswa pada pokok bahasan trigonometri di kelas XI MIA-3 MAN Sipirok. Hal ini dapat dilihat dari peningkatan kegiatan proses pembelajaran dalam keterampilan berpikir kritis siswa pada setiap siklus, terlihat pada siklus I pertemuan I dari 51,35\% menjadi $62,16 \%$ siklus I pertemuan II dan siklus II pertemuan I dari $75,68 \%$ menjadi $86,48 \%$ siklus II pertemuan II.

Dengan demikian keterampilan berpikir kritis siswa di kelas XI MIA-3 MAN Sipirok yang dicapai melalui metode Tutor Sebaya sudah mencapai persentase yang diharapkan yaitu persentase yang paling tinggi dalam penelitian ini yaitu $86,48 \%$.

Berdasarkan hasil penelitian, maka ada beberapa saran yang dapat dipergunakan sebagai bahan pertimbangan sebagai berikut:

1. Kepada kepala sekolah, agar memberikan pelatihan kepada guru-guru di sekolah tentang strategi pembelajaran, lebih mengoptimalkan pembelajaran dengan menggunakan metode tutor sebaya dan metode-metode lainnya.

2. Kepada guru, disarankan memanfaatkan tutor sebaya dalam proses pembelajaran untuk meningkatkan keterampilan berpikir kritis siswa.

3. Kepada siswa, hendaknya berperan aktif dan kritis dalam pembelajaran matematika, semakin memberanikan dan membiasakan diri untuk bertanya dan berani tampil maju ke depan sebagai Tutor dalam pembelajaran matematika maupun pembelajaran mata pelajaran yang lainnya.

4. Kepada peneliti selanjutnya, agar memperluas penelitian tentang metode Tutor Sebaya ini pada hal lain selain keterampilan berpikir kritis. 


\section{DAFTAR PUSTAKA}

Abuddin Nata, Perspektif Islam tentang Strategi Pembelajaran, Jakarta: Kencana Prenada Media Group, 2009.

Adiwarman, Sejarah Pemikiran Ekonomi Islam, Jakarta: PT. Pustaka Pelajar, 2001.

Ajeng Desi Crisandi Pritasari, Upaya Meningkatkan Kemampuan Berpikir Kritis

Siswa Kelas XI IPA 2 Sekolah Menengah Atas Negeri 8 Yogyakarta Pada Pembelajaran Matematika Melalui Pembelajaran Kooperatif Tipe Group Investigation (GI), Yogyakarta: tp. 2011.

Alec Fisher, Berpikir Kritis, Jakarta: Erlangga, 2008.

Suharsimi Arikunto, Prosedur Suatu Pendekatan Praktik, Jakarta: Rineka Cipta, 2006.

Aunurrahman, Belajar dan Pembelajaran, Bandung: Alfabeta, 2012.

Eveline Siregar dan Hartini Nara, Teori Belajar dan Pembelajaran, Jakarta: Ghalia Indnesia, 2010.

Diah Kusumaningsih, Upaya Meningkatkan Kemampuan Berpikir Kritis Siswa Kelas X-C SMA N 11 Yogyakarta Melalui Pembelajaran Matematika dengan Pendekatan Contextual Teaching And Learning (Ctl) pada Materi Perbandingan Trigonometri, Yogyakarta: tp. 2011.

Hasratuddin, Mengapa Harus Belajar Matematika?, Medan: Perdana Publishing, 2015.

Heri Rahyubi, Teori-teori Belajar dan Aplikasi Pembelajaran Motorik, Bandung: Nusa Media, 2012.

Heris Hendriana dan Utari Sumarmo, Penilaian Pembelajaran Matematika, Bandung: PT Refika Adimata, 2014.

Istarani, Kumpulan 40 Metode Pembelajaran, Medan: Media Persada, 2012.

Kosasih, E., Strategi Belajar dan Pembelajaran (Implementasi Kurikulum 2013). Bandung: Yrama Widya, 2014.

Marwanta dkk, Matematika SMA Kelas X, Jakarta Timur: Yudhistira, 2009.

Masitoh dan Laksmini Dewi, Strategi Pembelajaran, Jakarta: Direktorat Jenderal Pendidikan Islam Departemen Agama Islam, 2009.

Muhammad Surya, Strategi Kognitif dalam Proses Pembelajaran, Bandung: Alfabeta, 2015.

Nasimatul Wardiyyah, Penerapan Model Pembelajaran Tutor Sebaya untuk Meningkatkan Hasil Belajar Peserta Didik Kelas Vii Mts Nu Banat Kudus pada Materi Pokok Operasi Bilangan Pecahan Semester I Tahun Ajaran 2009/2010, Semarang: tp. 2009.

Ngalimun, Strategi dan Model Pembelajaran, Yogyakarta: Aswaja Presindo, 2013. 
Oemar Hamalik, Proses Belajar Mengajar, Jakarta: PT Bumi Aksara, 2011.

Rena Ayu Triyunita, Pengaruh Metode Tutor Sebaya Terhada Kemampuan Berpikir Kritis Siswa Kelas X SMA Negeri 3 Kediri Dalam Menyelesaikan Permasalahan Terkait Komposisi Fungsi (Artikel Skripsi: Universitas Nusantara PGRI Kediri, 2018).

Rinda Aryati Wahyudin, Metode Pembelajaran Tutor Sebaya Untuk Meningkatkan Kemampuan Pemahaman Konsep Matematika Siswa Kelas VII SMP Negeri 2 Teluk Jambe Timur. Prosiding Seminar Nasional Matematika dan Pendidikan Matematika (SESIOMADIKA), 2017.

Rofiqoh Nurhayati, Meningkatkan kemampuan Siswa dalam Menyelesaikan Soalsoal Cerita Operasi Bilangan Pecahan dengan Menggunakan Pendekatan Tutor Sebaya pada kelas VIIA SMP Negeri 3 Palangga.

Sanjaya, Hakikat Belajar dan Pembelajaran, Jakarta: Bumi Putra, 2007.

Siti Hardiyana, Rita Lefrida, Baso Amri, Penerapan Pendekatan Tutor Sebaya Untuk Meningkatkan Kemampuan Siswa Kelas VII SMP Negeri 1 Kasimbar Dalam Menyelesaikan Pertidaksaman Linear Satu Variabel, AKSIOMA Jurna Pendidikan Matematika Vol. 04 No. 02 September 2015.

Suharsimi Arikunto, Manajemen Penelitian, Jakarta: Rineka Cipta, 2007.

Suriyono, Teknik Belajar Mengjar dalam CBSA, Jakarta: PT.Rineka Cipta, 1992.

Tim Pengembangan MKDP Kurikulum dan Pembelajaran, Kurikulum dan Pembelajaran, Bandung: Raja Grafindo Persada, 2011.

Tukiran Taniredj dan Irma Pujiantj, Penelitian Tindakan Kelas, Bandung: Alfabeta, 2013. 